\title{
Effects of Medicated and Non-medicated Multi-nutrient Block Supplementation on Gastrointestinal Parasite Infestation and Blood Hematological Parameters of Lactating Saanen Goats
}

(Kesan Penambah Makanan Blok Pelbagai Nutrien Berubat dan Tidak Berubat pada Serangan Parasit Gastrousus dan Parameter Hematologi Darah Kambing Saanen dalam Tempoh Laktasi)

\author{
Mira PANADI*, WAN ZAHARI MOHAMED, NOR Dini RUSLI \& KHAIRIYAH MAT
}

\begin{abstract}
In a 90-day feeding trial, twenty four (24) Saanen lactating does were assigned to four treatment group. The treatments were feeding: basal diet only as a control (T1), basal diet with urea molasses multi-nutrient block (UMMB) (T2), basal diet with medicated urea molasses multi-nutrient block (MUMB) (T3) and basal diet with commercial mineral block (CMB) (T4). There were significant differences $(\mathrm{p}<0.05)$ between T2, T3 and T4 on the fecal egg count (FEC). Animals in T2 and T3 showed moderate level of parasite infestation i.e. at 750 epg and 950 epg, respectively, while animals in T1 and T4 showed severe parasite load at 4917 epg and 1850 epg, respectively. There were no significant differences (p $>0.05)$ between treatments on WBC, LYM, MON, GRA, RBC, HCT, MCV, MCH, PLT, MPV and PCT. However, significant effects ( $\mathrm{p}<0.05)$ on $H B G, M C H C, R D W$ and $P D W$ were observed in T2 and T3. This research showed that UMMB and MUMB were effective in controlling parasite infestation in Saanen lactating dairy goats apart from improving their blood hematological parameters. Comparison with CMB showed that it is practical to be used for parasite control.
\end{abstract}

Keywords: Hematological parameters; multi-nutrient block; MUMB; parasite infestation; Saanen

ABSTRAK

Dalam 90 hari ujian pemakanan, dua puluh empat (24) ekor kambing Saanen dalam tempoh laktasi dibahagikan kepada empat kumpulan rawatan, dengan setiap kumpulan terdiri daripada enam (6) ekor kambing. Pemakanan yang diterima oleh setiap kumpulan rawatan adalah: makanan asas sahaja (T1), makanan asas dan blok urea molas (UMMB) (T2), makanan asas dan blok urea molas berubat (MUMB) serta makanan asas dan mineral blok komersial (CMB) (T4). Didapati terdapat kesan signifikan $(\mathrm{p}<0.05)$ antara T2, T3 dan T4 terhadap kiraan telur parasit (FEC). Kambing pada T2 dan T3 menunjukkan kadar serangan parasit pada tahap pertengahan iaitu masing-masing 750 epg dan 950 epg manakala kambing pada T1 dan T4 menunjukkan serangan kronik iaitu 4917 epg dan 1850 epg. Kesan tidak signifikan ( $>$ >0.05) didapati terhadap WBC, LYM, MON, GRA, RBC, HCT, MCV, MCH, PLT, MPV dan PCT. Walau bagaimanapun, terdapat kesan signifikan $(\mathrm{p}<0.05)$ antara rawatan terhadap $H B G, M C H C, R D W$ dan PDW antara T2 dan T3. Keputusan kajian ini menunjukkan UMMB dan MUMB efektif dalam mengawal kadar serangan parasit pada kambing Saanen yang dalam tempoh laktasi dan juga memperbaiki parameter hematologi darah. Perbandingan dengan CMB membuktikan bahawa penambah makanan ini praktik dalam mengawal kadar serangan parasit.

Kata kunci: Blok pelbagai nutrien; MUMB; parameter hematologi; Saanen; serangan parasit

\section{INTRODUCTION}

The Department of Veterinary Service (2017) stated that in 2016, goat population in Malaysia was 446,854 heads with the largest population was found in Peninsular Malaysia, at about $85 \%$, followed by Sabah (12.0\%) and Sarawak (3\%). From year 2012 to 2016 , goat population in Malaysia was decreased by $3 \%$. In Malaysia, common feed resources for livestock feed were forages. There were abundant supply of grasses and legumes but eventually, problem often arise mostly related to the quality of the forages. Other feeds utilized include waste from agricultural by product such as palm kernel expeller (PKE), palm oil mill effluent (POME) and oil palm frond
(OPF). In small ruminant feeding system, $70 \%$ of local farmers in Malaysia practiced intensive feeding system which relies on approximately $40 \%$ commercial goat pellet and fodder. The remaining $30 \%$ of local farmers practiced semi intensive and extensive system which comprised of small and traditional farmers (Muhayat 2013).

However, in tropical countries, the main constraints that cause severe loss in ruminant industry are poor nutritional status and infestation of gastrointestinal parasites. Pneumonic pasteurellosis and endoparasitism were also recognized as the main disease that caused mortality in small ruminant animals (Chandrawathani 
2014). Both nutritional and parasitism are highly related as poor nutritional status can lead to severe parasite infestation. Overall, ruminant productivity was reduced due to the shortage of energy and protein, as well as parasitic disease and genetic inadequacies in the animals. When grazing ruminants are raised under extensive system, the common diets were native grasses and crop residues which contain only $<6 \%$ crude protein with high fibre content $(>25 \%)$ and deficient in other nutrients commonly minerals and vitamins (Wan Zahari et al.2007)

Commonly, low production and reproductive performance of livestock in the tropics are associated with mineral imbalances. This problem arises due to mineral imbalance in soil and forages (Zeleke 2015). In Malaysia, salt block supplementation is often practiced to overcome mineral deficiencies in ruminants. However, this approach can be considered not cost-effective as most of the salt blocks available in domestic markets are imported. Moreover, supplementation of salt blocks is not aimed at solving protein and energy deficiencies which are also common and widespread in Malaysia.

Under this condition, urea-molasses mineral blocks (UMMB) or medicated urea-molasses mineral blocks (MUMB) supplementation are more appropriate to be utilized as effective supplements as those are high in energy, nitrogen $(\mathrm{N})$ and macro-micro minerals. In order to precisely evaluate the health status of ruminants under supplementation, evaluations of blood level parameters give accurate measurements as blood profile reflects actual health status and can be referred to detect the presence of any subclinical disorders (Gwaze et al. 2012). Besides, blood constituents also influenced by the presence of endoparasitic and ectoparasitic activity (Kiourmarsi et al.2012). Hence, this trial was specifically conducted to determine effects of MUMB and UMMB on parasite infestation and blood haematological parameters in Saanen lactating does.

\section{MATERIALS AND METHODS}

\section{EXPERIMENTAL SITE AND CLIMATE}

This trial was carried out at Yusof Eco Farm, Felda Kemahang 1, Tanah Merah, Kelantan (latitude $5^{\circ} 41^{\prime} \mathrm{N}$ and longitude $101^{\circ} 50^{\prime} \mathrm{E}$ ) with the surrounding temperature at $26^{\circ} \mathrm{C}$ and $87 \%$ humidity. The study period was from 29 October 2016 to 27 December 2016. The raining season during the study was between ends of November until end of December with the mean rainfall was $600 \mathrm{~mm}$.

\section{EXPERIMENTAL ANIMALS}

Twenty four (24) Saanen lactating does were assigned to four treatment groups with six animals per group using a randomised complete block design (RCBD) based on initial body weight (mean initial body weight: $40.1 \mathrm{~kg}$ ). The goats were assigned for 10 days adaptation period following 90 days feeding trial. The goats were not dewormed or received any medication before the start of feeding trial.

\section{EXPERIMENTAL DIETS}

The goats were fed individually based on farm routine practice, in separate pens, subjected to the four dietary treatments i.e. T1: Basal diet only, T2: Basal diet+UMMB, T3: Basal diet+MUMB $(0.05 \%$ of fenbendazole per $\mathrm{kg}$ block), T4: Basal diet+CMB. Equal amount of fresh roughages ( $3 \mathrm{~kg} / \mathrm{day})$ and commercial goat pellet (1 $\mathrm{kg} /$ day) were fed separately to each animal, regardless of the treatment groups i.e. at 9.00 am and $12.00 \mathrm{pm}$, respectively. The supplements (UMMB, MUMB and CMB) were hanged inside the respective pens to allow ad libitum licking. The weight of each supplement was $2 \mathrm{~kg}$ and its replacement throughout the feeding trial was recorded. Table 1 shows the nutritional composition of basal diets and supplements.

TABLE 1. Nutritional composition (\%) of basal diets and supplements (Mean \pm SE)

\begin{tabular}{|c|c|c|c|c|c|}
\hline \multirow[t]{2}{*}{ Variables } & \multicolumn{5}{|c|}{ Basal feeds and supplements } \\
\hline & Roughages & $\begin{array}{c}\text { Commercial } \\
\text { goat pellet }\end{array}$ & UMMB & MUMB & $\mathrm{CMB}$ \\
\hline $\mathrm{DM}(\%)$ & $16.09 \pm 0.01$ & $91.19 \pm 0.08$ & $90.06 \pm 0.05$ & $90.13 \pm 0.03$ & $92.26 \pm 0.12$ \\
\hline Ash $(\%)$ & $5.33 \pm 0.01$ & $7.19 \pm 0.05$ & $17.48 \pm 0.10$ & $17.36 \pm 0.05$ & $95.05 \pm 0.05$ \\
\hline $\mathrm{OM}(\%)$ & $94.67 \pm 0.01$ & $92.81 \pm 0.08$ & $82.52 \pm 0.18$ & $82.64 \pm 0.08$ & $4.95 \pm 0.08$ \\
\hline $\mathrm{CP}(\%)$ & $15.54 \pm 0.05$ & $17.13 \pm 0.74$ & $33.84 \pm 0.07$ & $32.84 \pm 0.81$ & ND \\
\hline $\mathrm{CF}(\%)$ & $33.26 \pm 0.09$ & $20.07 \pm 0.33$ & $4.49 \pm 0.26$ & $4.07 \pm 0.22$ & ND \\
\hline $\mathrm{EE}(\%)$ & $2.44 \pm 0.08$ & $3.33 \pm 0.10$ & $0.55 \pm 0.11$ & $0.82 \pm 0.35$ & ND \\
\hline $\operatorname{ADF}(\%)$ & $41.41 \pm 0.72$ & $35.24 \pm 0.49$ & $5.47 \pm 0.09$ & $5.45 \pm 0.38$ & ND \\
\hline $\operatorname{NDF}(\%)$ & $65.77 \pm 0.20$ & $61.21 \pm 0.11$ & $10.51 \pm 0.48$ & $9.27 \pm 0.05$ & ND \\
\hline $\mathrm{Ca}(\mathrm{g} / \mathrm{kg})$ & $0.40 \pm 0.002$ & $3.86 \pm 0.006$ & $36.54 \pm 0.13$ & $34.95 \pm 0.11$ & $21.23 \pm 0.12$ \\
\hline $\mathrm{Cu}(\mathrm{mg} / \mathrm{kg})$ & $4.46 \pm 0.19$ & $0.97 \pm 0.6001$ & $0.70 \pm 0.004$ & $0.58 \pm 0.002$ & $8.23 \pm 0.03$ \\
\hline $\mathrm{Fe}(\mathrm{mg} / \mathrm{kg})$ & $10.69 \pm 0.07$ & $45.18 \pm 0.15$ & $11.27 \pm 0.03$ & $13.87 \pm 0.03$ & $259.07 \pm 1.11$ \\
\hline $\mathrm{Zn}(\mathrm{mg} / \mathrm{kg})$ & $1.83 \pm 0.01$ & $0.25 \pm 0.002$ & $1.84 \pm 0.02$ & $2.61 \pm 0.01$ & $21.27 \pm 0.22$ \\
\hline
\end{tabular}

SE, standard error; ND, not defined; UMMB, urea molasses multi-nutrient block; MUMB, medicated urea molasses multi-nutrient block; CMB, commercial mineral block 


\section{DATA COLLECTION AND ANALYSIS}

\section{PARASITE INFESTATION}

The parasite infestations were evaluated at Day $0,15,30$, 45, 60, 75 and 90 of the trial period (Doan et al. 2006). Fresh faecal sample were collected from the rectum of each animal and were kept in the ice box at $<5^{\circ} \mathrm{C}$ for analysis (Syomiti et al. 2015). Ground faecal sample (3 g) was mixed with $45 \mathrm{~mL}$ of saturated salt solution. It was filtered using a tea strainer and then transferred to McMaster slide. The parasite egg was counted under microscope of $10 \times 10$ magnification. The mean eggs per gram (epg) were identified based on the following formula: (Number of eggs in both chamber X 45)/ $(0.15 \times 3)$ (Hansen \& Perry 1994). Level of parasite infestation were classified as low, medium and severe if total epg were $<500,500-1000$ or $>1000$ epg respectively (Fernandez 2012).

\section{BLOOD HAEMATOLOGICAL PARAMETERS}

Blood haematological parameters were determined before and after the feeding trial. The measured haematological parameters were WBC, LYM, MON, GRA, RBC, HBG, HCT, MCV, MCH, MCHC, RDW, PLT, MPV, PCT, PDW. The blood samples were taken via jugular vein using 21 -gauge (1 1/2") vacutainer needle (Becton, Dickinson and Company $\mathbb{C}$, England) into $10 \mathrm{~mL}$ blood tube using K3 ethylene diamine tetra acetic acid (EDTA) (BD Vacutainer ${ }^{\circledR}$, US) as an anticoagulant. Haematological parameters were determined by blood analyser (Mythic 18 Vet M-pack, USA) and compared with the reference value (IDEXX, Inc., 2009) (Table 2).

TABLE 2. Reference value for various blood hematological parameters in goats

\begin{tabular}{lc}
\hline Hematological parameters & Reference range \\
\hline WBC $\left(10^{3} / \mu \mathrm{L}\right)$ & $4.0-12.0$ \\
LYM $\left(10^{3} / \mu \mathrm{L}\right)$ & $1.0-5.5$ \\
MON $\left(10^{3} / \mu \mathrm{L}\right)$ & $0.1-1.0$ \\
GRA $\left(10^{3} / \mu \mathrm{L}\right)$ & $4.0-8.0$ \\
RBC $\left(10^{3} / \mu \mathrm{L}\right)$ & $4.0-6.2$ \\
HBG $(\mathrm{g} / \mathrm{dl})$ & $11-17$ \\
HCT $(\%)$ & $35-55$ \\
MCV $\left(\mu \mathrm{m}^{3}\right)$ & $80-100$ \\
MCH $(\mathrm{pg})$ & $26-34$ \\
MCHC $(\mathrm{g} / \mathrm{dl})$ & $31.0-35.5$ \\
RDW $(\%)$ & $10-16$ \\
PLT $\left(10^{3} / \mu \mathrm{L}\right)$ & $150-400$ \\
MPV $\left(\mu \mathrm{m}^{3}\right)$ & $7-11$ \\
PCT $(\%)$ & $0.2-0.5$ \\
PDW $(\%)$ & $10-18$ \\
\hline
\end{tabular}

Source: IDEXX, Inc. (2009)

WBC, white blood cell; LYM, lymphocyte; MON, monocyte; GRA, granulocyte; RBC, red blood cell count; HBG, hemoglobin; HCT, hematocrit; MCV, mean corpuscular volume; $\mathrm{MCH}$, mean corpuscular hemoglobin; $\mathrm{MCHC}$, mean corpuscular hemoglobin concentration; RDW, red blood cell distribution width; PLT, platelet count; MPV, mean platelet volume; PCT, plateletcrit; PDW, platelet distribution width

\section{STATISTICAL ANALYSIS}

All data were analysed by Analysis of Variance using SPSS 23 (2015). Duncan Multiple Range Test was carried out at $5 \%$ significance level when significant differences were observed between treatments.

\section{RESULT AND DISCUSSION}

All treatment groups received similar type of daily feeds with the CP content of about $15.0 \%$ that met the requirement for lactating (Rashid 2008). Total dry matter intake (DMI) for T1, T2, T3 and T4 were $1.14 \pm 0.02,1.28 \pm 0.02,1.24 \pm 0.02$ and $1.15 \pm 0.02 \mathrm{~kg} / \mathrm{day}$ respectively, while the respective intakes of UMMB, MUMB and CMB were 87, 50 and $37 \mathrm{~g} / \mathrm{d}$ for T2, T3 and $\mathrm{T} 4$, respectively.

Table 3 shows mean worm egg count in different treatments. At the beginning of the trial, all goats in the treatment groups showed severe parasite infection as this research was carried out on natural parasite with infected goats as the goats did not receive any medication or treatment before feeding trial. There were no significant difference $(p>0.05)$ between treatments up to day 30 of feeding trial. Besides, there were increasing trend of total epg at the beginning of the trial up to day 30. In fact, Haemonchus spp. adult female parasite which commonly cause the major problem in small ruminants normally lay $>5000$ eggs per day. Thus, eggs laid in abomasum were discharged from body via faeces cause high parasite level during this period (Hepworth \& Hutchens 2006).

At day 45 and 90, there were significant differences $(p<0.05)$ between T2, T3 and T4 with T1. This indicated that the effect of supplementation was observed only after 45 days of the feeding period. During this period, the trend still increase in all treatments group but eventually, parasite infestation were significantly higher $(p<0.05)$ in control group as compared to the supplemented group which is at $4083 \pm 861$ epg. The effect was observed to be more severe at high humidity, especially during rainy reason (Suharyono et al. 2014) as faced by the animals from day 45 onwards. In rainy season, there were rapid development of larvae which only takes less than 2 weeks (Harwood 2006). Larvae egg which were consumed by the goats through feed were survived up to 180 days during the rainy season compared to normal survival rate at about 90 days in hot environment (Hepworth \& Hutchens 2006). However, the availability of additional protein, energy and minerals in UMMB and MUMB blocks as well mineral content through $\mathrm{CMB}$ supplementation had minimize the rapid increase of total epg.

At the end of feeding trial (day 90), goats supplemented with UMMB and MUMB were at moderate level of parasite infestation, with epg values of $750 \pm 275$ and $950 \pm 173$, respectively. The nutritional benefits attributed to UMMB and MUMB were evidenced as additional protein, energy and minerals were directly supplied to the animals, enhancing rate of growth and most likely, increased 
nutrient digestibility (Abid et al. 2016). As expected, goats supplemented with $\mathrm{CMB}$ showed severe parasite infection as CMB was devoid of protein and energy sources.

The finding of this study was also supported by Rafiq et al. (2004) which stated that UMMB supplementation had reduced parasite infestation at about $13.44 \%$ from $991 \pm 124$ to $941 \pm 131$ epg which is significantly lowered than un-supplemented animals. However, better result was recorded in MUMB group as parasite level had reduced by $92.73 \%$ i.e. from $977 \pm 98$ to $71 \pm 31 \mathrm{epg}$. In this current trial, higher UMMB intake was recorded than MUMB group lead to out-perform of UMMB group. The addition of fenbendazole cause bitter taste of the block which affect its palatability (Akbar et al. 2006).

In different findings, parasite infestation in animals supplemented with MUMB (425 $\pm 76 \mathrm{epg}$ ) was significantly lowered than UMMB $(1279 \pm 240$ epg) and un-supplemented group $(1619 \pm 402 \mathrm{epg})$. It was found that protein supplementation did not influence the initial establishment of parasite as at maintenance stage of the animals, UMMB supplementation did not affect the parasite infestation (Waruiru et al. 2017).

Other than factors such as nutritional deficiency and environmental factors, stage of development of goats also effect the susceptibility of parasite. Lactating goats tend to develop weaker immunity. Thus, they are not able to fight against parasite infestation (Hepworth \& Hutchens 2006). This condition is due to negative energy balance which occur during the lactating stage. During this stage, the energy reserved will be used mainly for milk production and only the balance energy will be used for other purposes (Tekeba et al. 2013). Larger mean standard errors were suggestive of large variation between individuals.

Table 4 shows that there were no significant effect $(p>0.05)$ of treatments on WBC, LYM, MON, GRA, RBC, HCT, MCV, MCH, PLT, MPV and PCT. Similar results were obtained by Konwar et al. (2015). However, current findings were contradictory to the findings of Hossain et al. (2011), Kioumarsi et al. (2012) and Li et al. (2014). The blood parameters of goats that were supplemented with UMMB and MUMB were within the normal ranges, which could be attributed to adequate nutrition as received by the goats to meet their daily nutritional requirements. Protein deficiency can cause low WBC and RBC (Ansah et al. 2011) while healthy LYM (1.0-5.5 103/ $\mu \mathrm{L})$, MON (0.1-1.0 103/ $\mu \mathrm{L})$, GRA $\left(2.0-8.010^{3} / \mu \mathrm{L}\right)$ and PLT (150-400 $10^{3} / \mu \mathrm{L}$ ) values reflect better immune system to fight against infection, allergies and inflammation (Ayoade et al. 2015; Park et al. 2012). Healthy НСТ (35-55 \%) value reflects minimum level of parasitic infection (Gendley et al. 2015) as has been shown by the UMMB and MUMB groups. Healthy MCV (80-100 $\left.\mu^{3}\right)$, MCH (26-34 pg) and MPV $\left(7-11 \mu \mathrm{m}^{3}\right)$ values indicated that the goats were free from anaemia, indication of sufficient oxygen carrying capacity of RBC and the absence of immature platelet respectively (Ayoade et al. 2015).

There were significant differences $(p<0.05)$ between treatments on $\mathrm{HBG}, \mathrm{MCHC}, \mathrm{RDW}$ and PDW. Significant HBG results in T2 and T3, was in agreement to Gendley et al. (2015). Improved HBG concentration due to UMMB and MUMB supplementation has also reflected better health status of the goat and indication of nutritional status of animals (Roza et al. 2015). However, significant decrease in $\mathrm{MCHC}$ value in $\mathrm{T} 4$ could be associated with iron $(\mathrm{Fe})$ deficiency.

Blood hematological parameters are important as indication of animal health and nutritional status. Factors such as physiological state, environmental condition, disease and stress are also known to influence blood hematological parameters (Etim et al. 2014).

\section{CONCLUSION}

The findings from this research indicated that locally produced UMMB and MUMB were superior to CMB in terms of nutritive value and effectiveness. Both supplements are high in protein and energy as compared to CMB. Parasite infestation was reduced by $31 \%$ and $25 \%$ with UMMB and MUMB supplementation, respectively.

TABLE 3. Mean \pm SE of epg between treatments

\begin{tabular}{|c|c|c|c|c|c|}
\hline $\begin{array}{l}\text { Period } \\
\text { (days) }\end{array}$ & $\mathrm{T} 1$ & $\mathrm{~T} 2$ & $\mathrm{~T} 3$ & $\mathrm{~T} 4$ & LS \\
\hline 0 & $1708 \pm 443$ & $1091 \pm 164$ & $1263 \pm 199$ & $1175 \pm 178$ & NS \\
\hline 7 & $2050 \pm 530$ & $1060 \pm 401$ & $2050 \pm 658$ & $1142 \pm 308$ & NS \\
\hline 15 & $2383 \pm 752$ & $1767 \pm 799$ & $1660 \pm 877$ & $1408 \pm 111$ & NS \\
\hline 30 & $2733 \pm 696$ & $1917 \pm 796$ & $1340 \pm 283$ & $1300 \pm 38$ & NS \\
\hline 45 & $4083 \pm 861$ & $2120 \pm 546$ & $1460 \pm 373$ & $1692 \pm 441$ & $*$ \\
\hline 60 & $1260 \pm 361$ & $1800 \pm 566$ & $988 \pm 177$ & $2067 \pm 621$ & NS \\
\hline 75 & $2380 \pm 583$ & $1840 \pm 615$ & $1075 \pm 625$ & $1783 \pm 513$ & NS \\
\hline 90 & $4917 \pm 289$ & $750 \pm 275$ & $950 \pm 173$ & $1850 \pm 467$ & $*$ \\
\hline
\end{tabular}

SE, standard error; T1, control group; T2, basal diet+UMMB; T3, basal diet+MUMB; T4, basal diet+CMB; LS, level of significance; NS, not-significant ( $>0$.05); $*$, significant at $p<0.05$ 
TABLE 4. Blood haematological parameters between treatments (Mean \pm SE)

\begin{tabular}{|c|c|c|c|c|c|c|}
\hline \multirow[t]{2}{*}{ Parameters } & \multirow[t]{2}{*}{ Period } & \multicolumn{4}{|c|}{ Treatments } & \multirow[t]{2}{*}{ LS } \\
\hline & & 1 & 2 & 3 & 4 & \\
\hline \multirow[t]{2}{*}{ WBC $\left(10^{3} / \mu \mathrm{L}\right)$} & Before & $16.90 \pm 1.94$ & $19.05 \pm 3.24$ & $17.82 \pm 4.14$ & $19.40 \pm 3.71$ & NS \\
\hline & After & $22.33 \pm 4.79$ & $15.18 \pm 1.37$ & $14.23 \pm 4.98$ & $19.53 \pm 3.94$ & NS \\
\hline \multirow[t]{2}{*}{ LYM $\left(10^{3} / \mu \mathrm{L}\right)$} & Before & $8.55 \pm 1.56$ & $9.27 \pm 2.73$ & $7.28 \pm 1.93$ & $10.57 \pm 2.32$ & NS \\
\hline & After & $11.02 \pm 2.73$ & $6.83 \pm 0.51$ & $7.33 \pm 3.21$ & $11.12 \pm 3.32$ & NS \\
\hline \multirow[t]{2}{*}{$\operatorname{MON}\left(10^{3} / \mu \mathrm{L}\right)$} & Before & $0.93 \pm 0.10^{\beta}$ & $0.98 \pm 0.09^{\beta}$ & $1.07 \pm 0.14$ & $0.87 \pm 0.14^{\beta}$ & NS \\
\hline & After & $1.25 \pm 0.22$ & $1.19 \pm 0.32$ & $1.08 \pm 0.46$ & $2.03 \pm 0.88$ & NS \\
\hline \multirow[t]{2}{*}{ GRA $\left(10^{3} / \mu \mathrm{L}\right)$} & Before & $7.42 \pm 0.63$ & $8.80 \pm 1.18$ & $9.48 \pm 2.21$ & $8.00 \pm 1.55$ & NS \\
\hline & After & $9.68 \pm 1.07$ & $6.13 \pm 1.00^{\beta}$ & $6.27 \pm 2.24^{\beta}$ & $8.20 \pm 1.64$ & NS \\
\hline \multirow[t]{2}{*}{$\mathrm{RBC}\left(10^{6} / \mu \mathrm{L}\right)$} & Before & $19.45 \pm 1.04$ & $19.93 \pm 1.48$ & $19.51 \pm 0.53$ & $16.40 \pm 2.57$ & NS \\
\hline & After & $15.54 \pm 1.70$ & $13.83 \pm 1.83$ & $13.40 \pm 3.62$ & $14.35 \pm 1.55$ & NS \\
\hline \multirow[t]{2}{*}{$\mathrm{HBG}(\mathrm{g} / \mathrm{dl})$} & Before & $8.15 \pm 0.42$ & $8.67 \pm 0.31$ & $7.87 \pm 0.20$ & $6.92 \pm 1.08$ & NS \\
\hline & After & $9.27 \pm 1.22^{\mathrm{ab}}$ & $11.00 \pm 2.42^{\mathrm{ab} \beta}$ & $6.65 \pm 2.06^{\mathrm{a}}$ & $14.72 \pm 4.54^{\mathrm{b} \beta}$ & $*$ \\
\hline \multirow[t]{2}{*}{$\mathrm{HCT}(\%)$} & Before & $36.45 \pm 2.05^{\beta}$ & $38.38 \pm 2.59^{\beta}$ & $37.23 \pm 1.66^{\beta}$ & $30.82 \pm 4.96$ & NS \\
\hline & After & $33.33 \pm 1.81$ & $35.90 \pm 1.32^{\beta}$ & $47.25 \pm 6.62^{\beta}$ & $26.53 \pm 2.89$ & NS \\
\hline \multirow[t]{2}{*}{$\operatorname{MCV}\left(\mu \mathrm{m}^{3}\right)$} & Before & $18.77 \pm 0.15$ & $18.95 \pm 0.10$ & $19.38 \pm 0.12$ & $18.65 \pm 0.26$ & NS \\
\hline & After & $21.97 \pm 1.99$ & $38.90 \pm 12.68$ & $27.48 \pm 7.92$ & $32.27 \pm 12.95$ & NS \\
\hline \multirow[t]{2}{*}{$\mathrm{MCH}(\mathrm{pg})$} & Before & $4.20 \pm 0.10$ & $4.48 \pm 0.42$ & $4.05 \pm 0.05$ & $4.22 \pm 0.14$ & NS \\
\hline & After & $10.08 \pm 4.44$ & $12.50 \pm 4.44$ & $6.87 \pm 2.84$ & $10.45 \pm 4.03$ & NS \\
\hline \multirow[t]{2}{*}{$\mathrm{MCHC}(\mathrm{g} / \mathrm{dl})$} & Before & $22.43 \pm 0.48$ & $23.60 \pm 2.19$ & $20.83 \pm 0.36$ & $22.67 \pm 0.78$ & NS \\
\hline & After & $23.22 \pm 1.05^{\mathrm{a}}$ & $25.34 \pm 1.98^{\mathrm{a}}$ & $23.30 \pm 1.86^{\mathrm{a}}$ & $28.58 \pm 1.56^{\mathrm{b}}$ & $*$ \\
\hline \multirow[t]{2}{*}{ RDW (\%) } & Before & $17.08 \pm 0.67^{\mathrm{a}}$ & $17.03 \pm 0.49^{\mathrm{a}}$ & $19.38 \pm 0.69^{\mathrm{a}}$ & $16.13 \pm 0.66^{b}$ & $*$ \\
\hline & After & $16.57 \pm 0.70^{\mathrm{ab}}$ & $14.20 \pm 1.33^{\mathrm{a} \beta}$ & $17.57 \pm 1.21^{\mathrm{b}}$ & $13.43 \pm 1.20^{\mathrm{a} \beta}$ & $*$ \\
\hline \multirow[t]{2}{*}{$\operatorname{PLT}\left(10^{3} / \mu \mathrm{L}\right)$} & Before & $143.33 \pm 24.82$ & $205.83 \pm 76.47$ & $93.33 \pm 12.93$ & $169.17 \pm 39.10^{\beta}$ & NS \\
\hline & After & $119.37 \pm 29.75$ & $109.00 \pm 4.49$ & $70.00 \pm 20.89$ & $169.17 \pm 30.50^{\beta}$ & NS \\
\hline \multirow[t]{2}{*}{$\operatorname{MPV}\left(\mu \mathrm{m}^{3}\right)$} & Before & $5.07 \pm 0.15$ & $4.98 \pm 0.17$ & $4.88 \pm 0.13$ & $4.97 \pm 0.16$ & NS \\
\hline & After & $5.45 \pm 0.58$ & $6.12 \pm 0.68$ & $5.33 \pm 0.75$ & $5.37 \pm 0.33$ & NS \\
\hline \multirow[t]{2}{*}{ PCT (\%) } & Before & $0.07 \pm 0.01$ & $0.11 \pm 0.04$ & $0.05 \pm 0.01$ & $0.08 \pm 0.02$ & NS \\
\hline & After & $0.19 \pm 0.08$ & $0.10 \pm 0.03$ & $0.22 \pm 0.14^{\beta}$ & $0.14 \pm 0.02$ & NS \\
\hline \multirow[t]{2}{*}{ PDW $(\%)$} & Before & $75.67 \pm 5.27$ & $75.75 \pm 8.29$ & $87.28 \pm 4.03$ & $73.30 \pm 4.62$ & NS \\
\hline & After & $60.62 \pm 11.57^{\mathrm{ab}}$ & $51.73 \pm 11.93^{\mathrm{ab}}$ & $79.20 \pm 9.48^{\mathrm{a}}$ & $49.80 \pm 11.05^{b}$ & $*$ \\
\hline
\end{tabular}

a,b Means in the same row with different superscript are significantly different $(p<0.05)$; SE, standard error; LS, level of significance; NS, not-significant $(p>0.05)$; significant at $p<0.05 ;{ }^{\beta}$ value lies within reference range

WBC, White blood cell; LYM, lymphocyte; MON, monocyte; GRA, granulocyte; RBC, red blood cell count; HBG, hemoglobin; HCT, hematocrit; MCV, mean corpuscular volume; $\mathrm{MCH}$, mean corpuscular hemoglobin; MCHC, mean corpuscular hemoglobin concentration; RDW, red blood cell distribution width; PLT, platelet count; MPV, mean platelet volume; PCT, plateletcrit; PDW, platelet distribution width

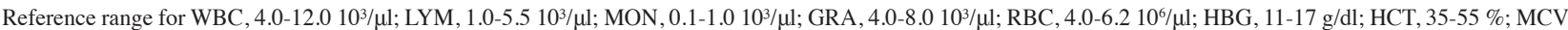

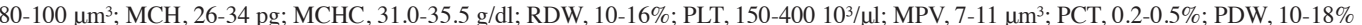

\section{ACKNOWLEDGEMENTS}

This research was fully funded by the Ministry of Higher Education, Malaysia under the FRGS grant scheme (R/FRGS/ A07.0/01083A/001/2015/000287). Our deepest gratitude to Mr. Mohd Nasaruddin bin Mohd Yusoff, the Managing Director of Yusof Ecofarm, Tanah Merah, Kelantan for providing the research facilities. Our gratitude also to the Deans, Faculty of Agro Based Industry and Faculty of Veterinary Medicine, Universiti Malaysia Kelantan for allowing us to use their laboratories.

\section{REFERENCES}

Abid, R., Khan, I., Bhatti, J.A., Shah, Z., Zahoor, A. \& Ahmad, S. 2016. Effect of medicated urea molasses blocks on subclinical parasitic infestations in goats. Online Journal of Animal and Feed Research 6(2): 57-71.

Akbar, M.A., Ahmed, T.U.\& Mondal, M.M.H. 2006. Improving animal productivity and reproductive efficiency: Development and testing medicated urea-molasses multi-nutrient blocks in rural farms of Bangladesh. In Improving Animal Productivity by Supplementary Feeding of Multi-nutrient Blocks, Controlling Internal Parasite and Enhancing Utilization of 
Alternate Feed Resource, edited by Makkar,H.P.S. \& Smith, T. Rome: Food and Agriculture Organization.

Ansah, T., Teye, G.A. \& Addah, W. 2011. Effect of wholecotton seed supplementation on growth performance and hematological properties of Djallonke sheep in the dry season. Journal of Animal and Feed Research 1(5): 155-159.

Ayoade, J.A., Wuanor, A.A. \& Ochepo, G.O. 2015. Performance, hematology and serum biochemistry of grazing Bunaji bulls supplemented varying levels and agro-industrial by-product based diet. Journal of Agriculture and Veterinary Science 8(8): 95-100.

Chandrawathani, P. 2014. Problems in the control of nematode parasites of small ruminants in Malaysia: Resistance to anthelmintic and biological control alternative. Ph.D Thesis. Swedish University of Agriculture Sciences, Sweden (Unpublished).

Department of Veterinary Service. 2017. Perangkaan ternakan 2015/2016. http://www.dvs.gov.my/index.php/pages/ view/1743. Accessed on 10 February 2018.

Doan, D.V., Nguyen, V.T., Nguyen, N.T. \& Ha, T.K.L. 2006. Development of urea-molasses multi-nutrient block (UMMB) and medicated UMMB (MUMB) for ruminants in Vietnam. In Improving Animal Productivity by Supplementary Feeding of Multinutrient Blocks, Controlling Internal Parasite and Enhancing Utilization of Alternate Feed Resource, edited by Makkar, H.P.S. Austria: International Atomic Energy Agency.

Etim, N.N., Williams, M.E., Akpabio, U. \& Offiong, E.E. 2014. Hematological parameters and factor affecting their values. Journal of Agriculture Science 2(1): 37-47.

Fernandez, D. 2012. Fecal egg counting for sheep and goat producers. https://www.uaex .edu/publications/pdf/FSA9608.pdf. Accessed on 4 April 2016.

Gendley, M.K., Tiwari, S.P., Dutta, G.K., Kumari, K. \& Ratre, H. 2015. Effect of urea molasses mineral block on hematological and biochemical blood parameters in adult goats. Indian Veterinary Journal 92(5): 98-100.

Gwaze,F.R., Chimonyo, M. \& Dzama, K. 2012. Effect of season and age on blood minerals, liver enzyme level and faecal egg count in Nguni goats of South Africa. Czech Journal of Animal Science 57(10): 443-453.

Hansen, J. \& Perry, B. 1994. The Epidemiology Diagnosis and Control of Helminth Parasites of Ruminants. A Handbook. Kenya: International Laboratory for Research and Animal Diseases.

Harwood, D. 2006. Goat Health and Welfare: A Veterinary Guide. Wiltshire: Crowood Press.

Hepworth, K. \& Hutchens, T. 2006. Managing internal parasitism in sheep and goats. Purdue Extension. College of Agriculture, University of Kentucky. pp. 1-10.

Hossain, F.M.A., Hasnath, M.R. \& Kabir, M.S. 2011. Hematobiochemical dynamics and body weight gain of Black Bengal goat following urea molasses block (UMB) supplementation. Online Journal of Animal and Feed Research 1(5): 182-185.

IDEXX, Inc. 2009. Reference value for goats mythic 18 vet M-pack hematology Analyzer. USA.

Kioumarsi, H., Yahaya, Z.S. \& Rahman, A.W. 2012. The effect of molasses/mineral blocks and medicated blocks on performance, efficiency and carcass characteristics of Boer goats. Annals of Biological Research 3(9): 4574-4577.

Konwar, P., Tiwari, S.P., Gohain, M. \& Kumari, K. 2015. The effects of protein dietary supplementation on fecal egg counts and hematological parameters in goat kids with subclinical nematodosis. Veterinary World 8(11): 1351-1355.

Li, H., Wang, K., Lang, L., Xu, Y., Zhang, Q., Zhu, W., Zhang, L., You, Y., Xu, F. \& Lu, W. 2014. The use of urea molasses multinutrient block on pica symptom of cattle. Journal of Food, Agriculture \& Environment 12(3 \& 4): 415-419.

Muhayat, F. 2013. Animal Feed Resources and Management in Malaysia. Bangkok Thailand. http://cdn.aphca.org/ dmdocuments/Events/FAOAPHCA_Regional_Workshop_ on_Animal_Feed_Resources_Bangkok/130814_S5 Malaysia_Muhayat.pdf. Accessed on 14 August 2017.

Park, J.H., Yoon, S.H., Kim, S.W., Shin, D., Jin, S.K., Yang, B.S. \& Cho, Y.M. 2012. Hematological and serum biochemical parameters of Korean native goats fed with spent mushroom substrate. Asian Journal of Animal and Veterinary Advances 7(11): 1139-1147.

Rafiq, K., Mostofa, M. \& Saiful, M. 2004. Studies of the antinematodal effects of medicated urea-molasses mineral blocks against gastrointestinal nematodiasis in indigenous dairy cows of Bangladesh. Pakistan Journal of Biological Science 7(1): 73-78.

Roza, E., Aritonang, S.N. \& Sandra, A. 2015. The hematology of lactating buffalo fed local foliage as feed supplement. Journal of Agricultural Science and Technology 5: 839-845.

Suharyono, Sutanto, H., Purwanti, Y., Martanti, Agus, A. \& Utomo, R. 2014. The effect of urea molasses multi-nutrient and medicated block for beef cattle, beef and dairy cow. Atomic Indonesia 40(2): 77-87.

Syomiti, M., Dana, H., Getachew, G., Beatrice, M. \& Wamae D. 2015. Medicated Prosopis spp.-based feed blocks for anthelmintic efficacy and performance of weaner lambs. Livestock Research for Rural Development 27(3): Article \#50.

Tekeba, E., Wurzinger, M., Baldinger, L. \& Zollitsch, W.J. 2013. Effects of dietary supplementation with urea molasses multi-nutrient block on performance of mid lactating local Ethiopia and crossbred dairy cows. Livestock Research for Rural Development 25(6): Article \#96.

Wan Zahari, M., Chandrawathani, P., Sani, R.A., Nor Ismail, M.S. \& Oshibe, A. 2007. Production and evaluation of medicated urea-molasses mineral blocks for small ruminants in Malaysia. In Feed Supplementation Blocks. Urea Molasses Multi-Nutrient Blocks: Simple and Effective Feed Supplement Technology for Ruminant Agriculture, edited by Makkar, H.P.S., Sanchez, M. \& Speedy, A.W. Rome: Food and Agriculture Organization.

Waruiru, R.M., Munyua, W.K., Mavuti, S.K., Otieno, R.O., Mutune, M.N. \& Maina, V.M. 2017. Effects of medicated urea-molasses block supplementation on productivity and gastrointestinal nematode infestation of sheep in central Kenya. Livestock Research for Rural Development 29(8): Article \#161.

Zeleke, M. 2015. Effects of dietary inclusion on mineral supplements with concentrates on nutrient utilization and economic efficiency of sheep fed hay as basal diet. Master Thesis. Haramaya University, Ethiopia (Unpublished).

Mira Panadi*, Nor Dini Rusli \& Khairiyah Mat

Faculty of Agro Based Industry

Universiti Malaysia Kelantan

Locked Beg No 100

17600 Jeli, Kelantan Darul Naim

Malaysia 
Wan Zahari Mohamed

Faculty of Veterinary Medicine

Universiti Malaysia Kelantan

Locked Bag No 36, Pengkalan Chepa

16100 Kota Bharu, Kelantan Darul Naim

Malaysia

Nor Dini Rusli

Institute of Food Security and Sustainable Agriculture

Universiti Malaysia Kelantan

Locked Bag No 100

17600 Jeli, Kelantan Darul Naim

Malaysia
*Corresponding author; email: mirapanadi@gmail.com

Received: 13 November 2017

Accepted: 8 March 2018 